\title{
Relations of drug use and socioeconomic factors with adherence to dental treatment among adolescents
}

\author{
Sílvia Letícia Freddo ${ }^{1 *}$, Inara Pereira da Cunha ${ }^{2} \mathbb{D}$, Jaqueline Vilela Bulgareli ${ }^{1}$, Yuri Wanderley Cavalcanti ${ }^{3}$ and \\ Antonio Carlos Pereira ${ }^{1}$
}

\begin{abstract}
Background: Adolescents are vulnerable to behaviors that weaken health, by adopting habits that interfere with adherence to treatment. The aims of the present study were to investigate adolescents' adherence to dental treatment and the relations between this behavior and socioeconomic factors and consumption of licit and illicit chemical substances.

Methods: A longitudinal study was conducted with 474 adolescents from Piracicaba/SP/Brazil, who initially underwent a dental examination to verify the adherence for dental treatment. After 18 months, 325 adolescents were reassessed. Valid questions about socioeconomic conditions and use of alcohol and drugs were applied to participants. The chi-square test and Fisher's exact test were used. The prevalence ratios were estimated with the respective 95\% confidence intervals, using generalized linear models with Poisson distribution.
\end{abstract}

Results: Eighteen (18) months after the first consultation, 325 adolescents were reassessed: 161 (49\%) did not adhere to the treatment, and 164 (51\%) adhered to it and answered the socioeconomic and alcohol and illicit drug questionnaires. Their mean age was $15 \pm 1$ years; of them, 189 (58\%) were female. The prevalence of adherence to treatment decreased in patients without their own home $(p=0.034)$. In the individual analysis of the variables, drinking alcohol alone, experimenting with drugs, and proximity of friends who consumed illicit substances were associated with the outcome $(p<0.05)$. However, in the joint analysis, only proximity of friends who consumed drugs was the factor related to low adherence to dental treatment among the adolescents $(p=0.035)$.

Conclusion: Adolescents who consumed alcohol and socialized with friends who used illicit drugs had greater difficulty in adhering to dental treatment.

Keywords: Adhesion, Illicit drugs, Oral health

\section{Background}

According to data from the World Drug Report, the most commonly used illicit drugs are: marijuana, amphetamines, opioids and cocaine, respectively. The type of drug used in the world is not uniform. In America, the most commonly used drug is cocaine, while in Europe and Asia the most common types used are opioids [1].

\footnotetext{
* Correspondence: freddente@hotmail.com

${ }^{1}$ Department of Community Dentistry, Piracicaba Dental School, State University of Campinas, Av. Limeira, 901, P.O. BOX 52, Piracicaba, SP 13414-903, Brazil

Full list of author information is available at the end of the article
}

Illicit drugs are prohibited by law. Legalized drugs, produced, consumed and marketed without restrictions are considered licit. Among the licit types, those most consumed by the Brazilian population are alcohol and tobacco [2]. The WHO has warned that the fact that there is no legislative ban on licit drugs makes them dangerous. While illicit drugs account for $0.8 \%$ of global health problems, alcohol and tobacco together account for $8.1 \%$ of the world's health problems [3].

Through appeals made by the media, they encourage the consumption of alcohol and cigarettes among adolescents, transforming this incentive of consumption into a rite of passage into adulthood [4].

(c) The Author(s). 2018 Open Access This article is distributed under the terms of the Creative Commons Attribution 4.0 International License (http://creativecommons.org/licenses/by/4.0/), which permits unrestricted use, distribution, and reproduction in any medium, provided you give appropriate credit to the original author(s) and the source, provide a link to the Creative Commons license, and indicate if changes were made. The Creative Commons Public Domain Dedication waiver (http://creativecommons.org/publicdomain/zero/1.0/) applies to the data made available in this article, unless otherwise stated. 
In Brazil, approximately 21 million boys and girls experience a period of development and maturation both physical and psychological, known as adolescence [5]. This is the phase of construction of the individual's autonomy, a phase of adopting practices that were previously determined mainly by parents or guardians [6]. In this scenario of transformations, adolescents may become more vulnerable to behaviors that weaken health. Where oral health is concerned, eating habits and neglect of oral hygiene are preponderant factors for the establishment of oral diseases [7, 8].

Despite extensive coverage and investment, making use of health services results from of the interaction of multiple factors [9]. Thus, merely offering the services does not guarantee their use and access to them by the population [10,11]. Among the factors involved in the use of dental services are social disparities, economic conditions and educational level [12, 13].

Non-adherence to treatment, due to its magnitude, is a public health problem, as it is related to the involvement and aggravation of oral diseases, negatively affecting adolescents' quality of life $[14,15]$. The present study adopted the concept of "adherence", as the decision to seek a health service and finish the recommended treatment. Attitudes opposed to this idea were considered non-adherence [16].

The adherence to treatment may also be related to socioeconomic factors and cultural habits. Among adults, the consumption of alcohol and illicit drugs impairs the acceptance of medical recommendations [17]. In the adolescence, regular consumption of licit substances causes less demand for preventive services [18]. However, there is a scarcity of studies of this behavior among adolescents with a focus on adherence to dental treatment, especially with a longitudinal approach, showing evidence of the novelty of the theme.

Therefore, the aims of this study were to investigate adolescents' adherence to dental treatment and the relations of this behavior with socioeconomic factors and consumption of licit and illicit chemical substances.

\section{Method}

This research was approved by the Research Ethics Committee of Unicamp, Protocol no. 027/2011, in accordance with Resolution 466/12 of the National Health Council, concerning research with human beings. The Term of Free and Informed Consent (TFIC) was signed by those responsible for the adolescents.

\section{Initial phase}

This was a longitudinal analytical study whose target population was adolescents from 15 to 19 years old living in Piracicaba, who attended the health units in which they were registered in the year 2015 .
The municipality of Piracicaba has a population of 391,449 inhabitants, in which 28,539 adolescents live in the municipality. The sample size was calculated based on previous studies [19, 20]. The sample of baseline study was based on the caries experience in the Southeastern region of Brazil, using data from a previous national epidemiological survey, considering a sampling error of $5 \%, \mathrm{DMFT}=5.16$ with $\mathrm{SD}=4.54$, sample loss of $20 \%$ and a level of confidence $95 \%$, thus obtaining a sample of 1428 individuals aged 15 to 19 years, proportionally and randomly taken from 34 Primary Health Care Units (PHCU) in areas existent in the municipality. Of these 1428 adolescents initially selected, 249 failed to appear on the day of the exam or did not wish to participate. Thus, 1179 adolescents were examined. The majority of them had lived in the same suburb since their birth.

The inclusion criteria were to have participated in the baseline study and to be enrolled in the PHCU.

\section{Final phase (study of adherence)}

Prior to this research, the oral health and quality of life of 1179 adolescents were evaluated in Baseline. Of these, 474 were referred for dental treatment. After 18 months, 325 adolescents were reassessed. The loss of 149 individuals, equivalent to $31.5 \%$ of the total sample, was due to: change of address or contact telephone number - 131 (88\%); Transfer to another municipality - 9 (1\%) and refusal of new participation - 9 (1\%). Nevertheless, authors consider data was not biased due to the participants withdraw. No statistically significant differences were detected between the socioeconomic data of all initially enrolled participants $(n=474)$ and those maintained at the follow up $(n=325)$.

For better visualization of this study design, Fig. 1 (Bulgareli, 2016) [21] explains the sequence of the developmental stages of the study.

About 18 months after Baseline, the researchers conducted an active search to locate the adolescents who were referred for dental treatment in the baseline.

The data collected in the final phase of the study were adherence to dental treatment and experience of alcohol and illicit drugs consume. The dental tratament adherence was considered as the decision to seek a health service and finish the recommended treatment. The clinical examination was carried out to verify those individuals with absence of caries and peridontal disease that is adherence to dental treatment.

The process of calibrating the two examiners for the clinical conditions was conducted by a Gold Standard examiner, and followed a similar methodology from a previously published study [20]. Theoretical-practical activities were performed: 1 theoretical $(4 \mathrm{~h}), 4$ clinical training sessions ( $4 \mathrm{~h}$ each), 2 calibration 


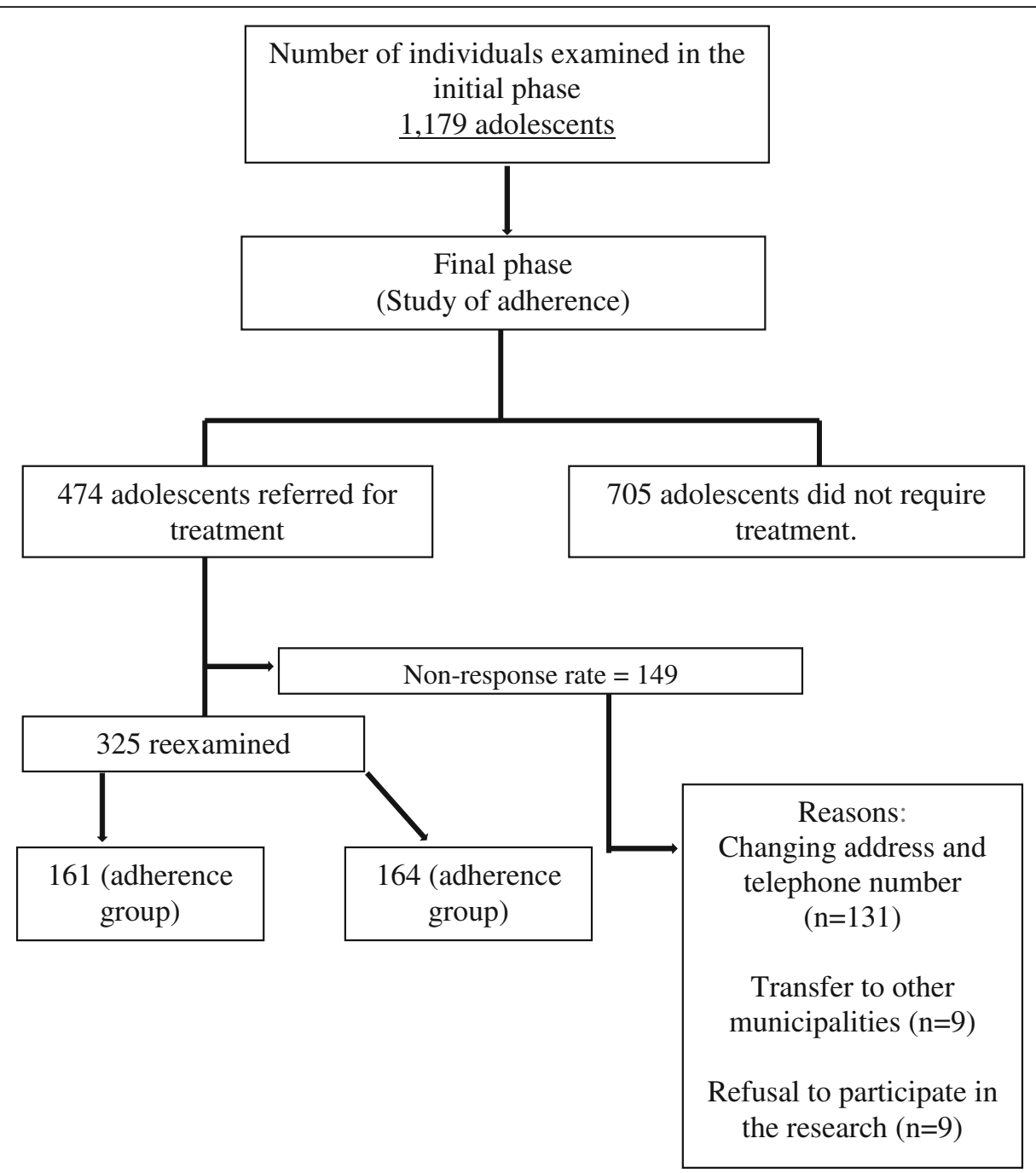

Fig. 1 Representative flowchart of the study phases (Bulgareli, 2016) [21]

exercises ( $4 \mathrm{~h}$ each). The training stage consisted of a theoretical discussion, followed by a practical stage, in which the examiners evaluated 12 adolescents per period. The final calibration exercise consisted of 2 periods (total of $8 \mathrm{~h}$ ) with mean inter-examiner Kappa values of 0.95 . For the purpose of verifying maintenance of the diagnostic criteria and intraexaminer error, $10 \%$ of the sample were re-examined, showing a mean Kappa value of 0.96 for all the clinical conditions.

\section{Study variables}

Data were collected by previously trained, calibrated examiners, using four self-administered questionnaires and clinical dental examination to verify adherence. The first questionnaire developed for the purposes of this study provided data regarding adherence to dental treatment, considering the outcome of the study. It was elaborated by the researcher of the study. The second questionnaire was developed the World Health Organization [22] and provided data on use (experience) of alcohol and illicit drugs. In the baseline the collected variables were socioeconomic characterization (family income, father's and mother's literacy, type of housing) [23] and data on adolescents' school failure and their insertion into the labor market obtained by means of the Goes questionnaire (2001) [24].

The dependent variable of the study was adherence to dental treatment and the independent types were use (experience) of alcohol and illicit drugs, both collected in the final phase and socioeconomic factors (family income, father's and mother's literacy, type of housing, Work and school failure). The adolescents' sex and age were also considered independent variables collected in the final phase (Fig. 2). 


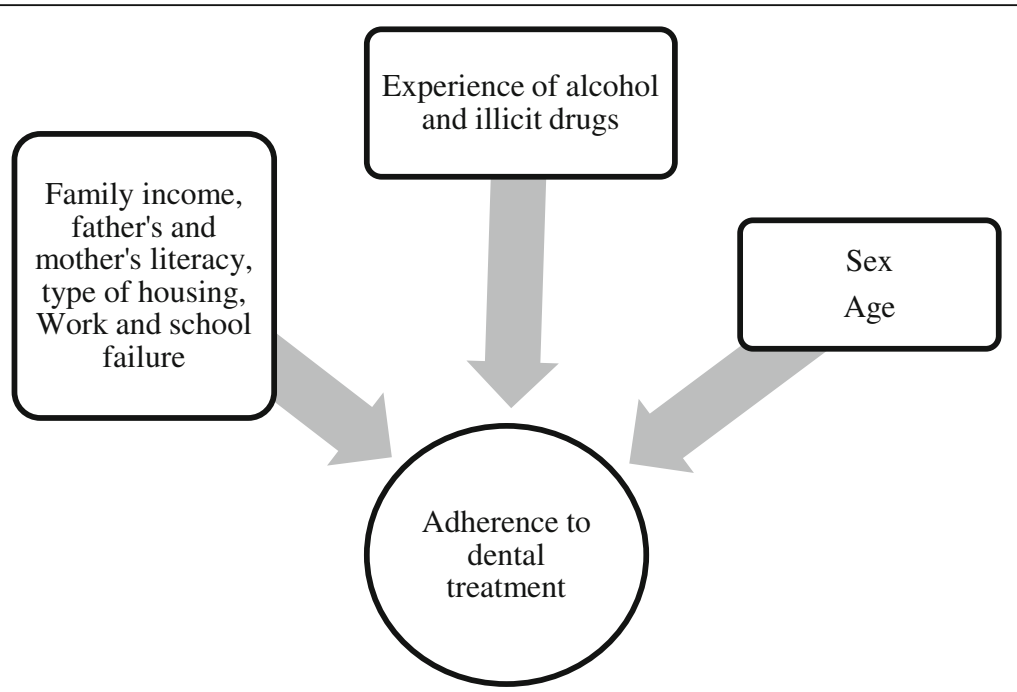

Fig. 2 Theoretical Model for Study of Association between Independent Variables and Adherence to Dental Treatment

\section{Data analysis}

In the data analysis, the quantitative characteristics were described according to adherence by using mean and standard deviation and the groups compared according to adherence using the Student's- $t$ test. The qualitative characteristics evaluated were described according to adherence with the use of absolute and relative frequencies. In addition, Chi-square and Fisher's exact tests or likelihood ratio tests were used to verify whether there was association with adherence [25].

The prevalence ratios were estimated with the respective 95\% confidence intervals, using generalized linear models with Poisson distribution and logarithmic link function for each parameter evaluated [26]. All the prevalence values were adjusted by age. The joint model of the characteristics evaluated was estimated to explain the adherence to treatment with the variables that presented a descriptive level lower than $0.2(p<0.2)$ in the bivariate tests, by using the same analysis methodology.

The analyses were performed using IBM-SPSS for Windows software version 20.0 and the tables were elaborated using Microsoft-Excel 2003 software. The tests were performed with significance level of $5 \%$.

\section{Results}

A total of 325 adolescents were evaluated; of these, 189 (58\%) were female and $136(42 \%)$ were male. Of the total sample, 164 (51\%) adolescents adhered to treatment and 161 (49\%) did not. Among those who adhered, 96 (58\%) were female and $68(42 \%)$ male. The mean age of the total sample was $15 \pm 1$ years.

Relative to the socioeconomic data of the families of the 164 adherents, 46 (29\%) adolescents had income higher than 1 or up to 2 minimum wages. As regards their parents, 49 (32.5\%) had a literacy level of up to 2nd grade incomplete, a value lower than that of the mother's literacy level. The type of dwelling that prevailed was their own residence, 125 (77.6\%). Considering school achievement and insertion in the labor market, 131 (81\%) never failed in school and $134(82 \%)$ did not work (Table 1$)$. There was no statistically significant difference between the family income of the adolescents and the outcome.

Table 1 - from the personal characteristics evaluated, in isolation - shows only the type of housing had a statistically significant influence on adherence to treatment $(p=0.034)$, and the prevalence of adherence to treatment decreased in patients without their own home.

As regards alcohol consumption, 105 participants (64\%) reported having previously tried some type of alcoholic drink, and 30 adolescents (18.5\%) used it for the first time, in the home. When asked about alcohol consumption in the last 30 days, 41 (25\%) reported having consumed it; $16(10 \%)$ answered that they had problems due to alcohol, and 10 (6\%) had problems once or twice in that period. Relative to alcohol abuse, $37(23 \%)$ of the adolescents reported having become really drunk, and for 31 of them (19\%), the frequency was one to two times.

When asked who they used to drink with, 57 (35\%) drank with their friends. In the comparison between groups, the variables "tried alcohol" $(p=0.035)$ and "drinking alone" ( $p=0.029)$ were statistically significant.

As regards drug use, 155 (96.9\%) of the adolescents had never tried drugs; only four of them (2.5\%) reported having used drugs in the last 30 days; and three $(1.8 \%)$ of them reported the frequency as being once or twice. With reference to their circle of 
Table 1 Description of the personal characteristics of the adolescents according to adherence and results of the statistical tests

\begin{tabular}{|c|c|c|c|c|c|c|}
\hline \multirow[t]{2}{*}{ Variable } & \multirow[t]{2}{*}{ Total $(N=325)$} & \multicolumn{2}{|l|}{ Adherence } & \multicolumn{3}{|c|}{$\mathrm{Cl}(95 \%)$} \\
\hline & & Yes $(N=164)$ & PR & Lower & Upper & $p$ \\
\hline Sex, n (\%) & & & & & & 0.962 \\
\hline Female & $189(58.2)$ & $96(58.3)$ & 1.00 & & & \\
\hline Male & $136(41.8)$ & $68(41.7)$ & 1.00 & 0.80 & 1.24 & \\
\hline Age (years) & & & 0.91 & 0.81 & 1.03 & $0.122^{b}$ \\
\hline mean $\pm S D$ & $15.2 \pm 1$ & $15.1 \pm 0.94$ & & & & \\
\hline Income, n (\%) & & & & & & $0.742^{\mathrm{a}}$ \\
\hline $1 \mathrm{MW}$ & $26(8.2)$ & $12(7.5)$ & 1.00 & & & \\
\hline+1 up to $2 \mathrm{MW}$ & $102(32)$ & $46(28.7)$ & 0.98 & 0.61 & 1.56 & \\
\hline+2 up to $3 \mathrm{MW}$ & $77(24.1)$ & $38(23.8)$ & 1.07 & 0.67 & 1.72 & \\
\hline+3 up to $5 \mathrm{MW}$ & $69(21.6)$ & $38(23.8)$ & 1.19 & 0.75 & 1.90 & \\
\hline+5 up to $7 \mathrm{MW}$ & $19(6)$ & $10(6.2)$ & 1.14 & 0.63 & 2.07 & \\
\hline+7 up to $10.5 \mathrm{MW}$ & $17(5.3)$ & $11(6.9)$ & 1.40 & 0.81 & 2.42 & \\
\hline$+10.5 \mathrm{MW}$ & $9(2.8)$ & $5(3.1)$ & 1.20 & 0.59 & 2.46 & \\
\hline Father's education, n (\%) & & & & & & 0.239 \\
\hline Illiterate up to some 4 th grade incomplete & $22(7.4)$ & $7(4.6)$ & 1.00 & & & \\
\hline $\begin{array}{l}\text { 4th grade complete or } 5 \text { th to } 8 \text { th grade } \\
\text { incomplete }\end{array}$ & $84(28.1)$ & $49(32.5)$ & 1.83 & 0.97 & 3.47 & \\
\hline 8th grade complete or high school incomplete & $96(32.1)$ & $49(32.5)$ & 1.60 & 0.84 & 3.05 & \\
\hline High school or incomplete college & $78(26.1)$ & $37(24.5)$ & 1.49 & 0.77 & 2.87 & \\
\hline College degree & $19(6.4)$ & $9(6)$ & 1.49 & 0.69 & 3.23 & \\
\hline Mother's education (\%) & & & & & & 0.167 \\
\hline Illiterate up to some 4 th grade incomplete & $16(5)$ & $7(4.3)$ & 1.00 & & & \\
\hline $\begin{array}{l}\text { 4th grade complete or } 5 \text { th to } 8 \text { th grade } \\
\text { incomplete }\end{array}$ & $71(22.2)$ & $28(17.4)$ & 0.90 & 0.48 & 1.69 & \\
\hline 8th grade complete or high school incomplete & $122(38.1)$ & $70(43.5)$ & 1.31 & 0.74 & 2.33 & \\
\hline High school or incomplete college & $86(26.9)$ & $42(26.1)$ & 1.12 & 0.62 & 2.03 & \\
\hline College degree & $25(7.8)$ & $14(8.7)$ & 1.28 & 0.66 & 2.46 & \\
\hline Housing, n (\%) & & & & & & 0.034 \\
\hline Owner & $233(72.4)$ & $125(77.6)$ & 1.00 & & & \\
\hline Not owner & $89(27.6)$ & $36(22.4)$ & 0.75 & 0.57 & 1.00 & \\
\hline School Failure, n (\%) & & & & & & 0.413 \\
\hline No & $256(79)$ & $131(80.9)$ & 1.00 & & & \\
\hline Yes & $68(21)$ & $31(19.1)$ & 0.89 & 0.67 & 1.19 & \\
\hline Employment, n (\%) & & & & & & 0.466 \\
\hline No & $262(80.6)$ & $134(82.2)$ & 1.00 & & & \\
\hline Yes & $63(19.4)$ & $29(17.8)$ & 0.90 & 0.67 & 1.21 & \\
\hline
\end{tabular}

Source: Elaborated by the author based on data from the city of Piracicaba

MW Abbreviation for minimum wage. Chi-square test; ${ }^{a}$ Probability ratio test; ${ }^{b}$ Student's- $t$ test; $P R$ Prevalence Ratio, $C l$ Confidence Interval; Not all patients had all the information; \& this could not be estimated

friends, $56(34.4 \%)$ reported that their friends did some type of drug. There was a significant association between nonadherence to dental treatment and having friends who did drugs $(p=0.005)$ and the variable relative to those who experienced drugs was also statistically significant $(p=0.049)$.
The factors having experienced alcohol, drinking alone, having tried drugs and having friends who did drugs had a single influence on the prevalence of adherence to dental treatment $(p<0.05)$, all of which decreased the prevalence of adherence to treatment when these parameters were present (Table 2). 
Table 2 Description of alcohol and drug consumption characteristics of the adolescents according to adherence and results of statistical tests

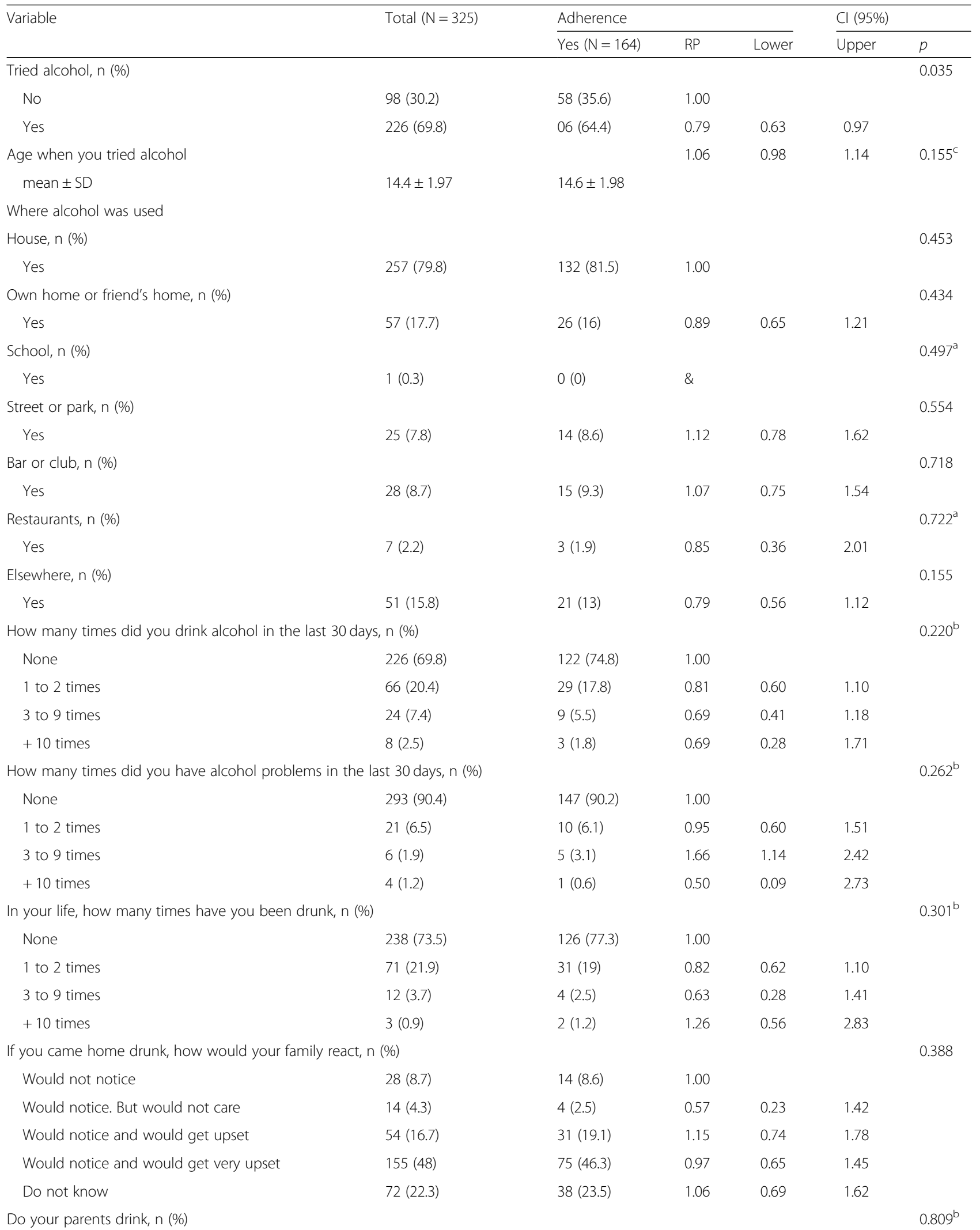


Table 2 Description of alcohol and drug consumption characteristics of the adolescents according to adherence and results of statistical tests (Continued)

\begin{tabular}{|c|c|c|c|c|c|c|}
\hline \multirow[t]{2}{*}{ Variable } & \multirow[t]{2}{*}{ Total $(\mathrm{N}=325)$} & \multicolumn{3}{|l|}{ Adherence } & \multicolumn{2}{|c|}{$\mathrm{Cl}(95 \%)$} \\
\hline & & Yes $(N=164)$ & $\mathrm{RP}$ & Lower & Upper & $p$ \\
\hline No & $149(46)$ & $73(44.8)$ & 1.00 & & & \\
\hline Father & $100(30.9)$ & $48(29.4)$ & 0.98 & 0.75 & 1.27 & \\
\hline Mother & $22(6.8)$ & $13(8)$ & 1.21 & 0.82 & 1.77 & \\
\hline Both & $50(15.4)$ & $27(16.6)$ & 1.10 & 0.81 & 1.49 & \\
\hline Do not know & $3(0.9)$ & $2(1.2)$ & 1.36 & 0.60 & 3.08 & \\
\hline Drink alcohol, n (\%) & & & & & & 0.222 \\
\hline No & $164(50.6)$ & $88(54)$ & 1.00 & & & \\
\hline Yes & $160(49.4)$ & $75(46)$ & 0.87 & 0.70 & 1.09 & \\
\hline Drink with friends, n (\%) & & & & & & 0.145 \\
\hline No & $198(61.1)$ & $106(65)$ & 1.00 & & & \\
\hline Yes & $126(38.9)$ & $57(35)$ & 0.85 & 0.67 & 1.07 & \\
\hline Drink with family members, n (\%) & & & & & & 0.746 \\
\hline No & $290(89.5)$ & $145(89)$ & 1.00 & & & \\
\hline Yes & $34(10.5)$ & $18(11)$ & 1.06 & 0.76 & 1.48 & \\
\hline Drink with other people, n (\%) & & & & & & $>0.999^{\mathrm{a}}$ \\
\hline No & $317(97.8)$ & $159(97.5)$ & 1.00 & & & \\
\hline Yes & $7(2.2)$ & $4(2.5)$ & 1.14 & 0.59 & 2.18 & \\
\hline Drink alone, n (\%) & & & & & & $0.029^{a}$ \\
\hline No & $319(98.5)$ & $163(100)$ & 1.00 & & & \\
\hline Yes & $5(1.5)$ & $0(0)$ & $\&$ & & & \\
\hline Tried drugs, n (\%) & & & & & & 0.049 \\
\hline No & $306(94.4)$ & $158(96.9)$ & 1.00 & & & \\
\hline Yes & $18(5.6)$ & $5(3.1)$ & 0.54 & 0.25 & 1.14 & \\
\hline Age when tried drugs & & & 0.81 & 0.52 & 1.25 & $0.426^{c}$ \\
\hline média \pm SD & $14.8 \pm 1.38$ & $14.4 \pm 1.52$ & & & & \\
\hline Did any type of drugs in the past 90 days, $n(\%)$ & & & & & & $0.540^{\mathrm{a}}$ \\
\hline No & $314(96.9)$ & $159(97.5)$ & 1.00 & & & \\
\hline Yes & $10(3.1)$ & $4(2.5)$ & 0.79 & 0.37 & 1.70 & \\
\hline \multicolumn{2}{|c|}{ How many times have used any drugs in the past 30 days, $n$ (\%) } & & & & & $0.445^{b}$ \\
\hline None & $314(96.9)$ & $159(97.5)$ & 1.00 & & & \\
\hline 1 to 2 times & $5(1.5)$ & $3(1.8)$ & 1.19 & 0.57 & 2.44 & \\
\hline 3 to 9 times & $1(0.3)$ & $0(0)$ & $\&$ & & & \\
\hline+10 times & $4(1.2)$ & $1(0.6)$ & 0.49 & 0.09 & 2.70 & \\
\hline Your friends do drugs, n (\%) & & & & & & 0.005 \\
\hline No & $188(58)$ & $107(65.6)$ & 1.00 & & & \\
\hline Yes & $136(42)$ & $56(34.4)$ & 0.72 & 0.57 & 0.92 & \\
\hline You do drugs, n (\%) & & & & & & 0.347 \\
\hline No & $313(96.6)$ & $159(97.5)$ & 1.00 & & & \\
\hline Yes & $11(3.4)$ & $4(2.5)$ & 0.72 & 0.32 & 1.58 & \\
\hline
\end{tabular}

Source: Elaborated by the author based on data from the city of Piracicaba.Chi-square test; ${ }^{\mathrm{a}}$ Fisher exact test; ${ }^{\mathrm{b}}$ Probability ratio test; ${ }^{\mathrm{c}}$ Student's t-test; $P R$ Prevalence Ratio, Cl Confidence Interval; Not all patients have all the information; \& it cannot be estimated 
Table 3 Result of the joint model to explain adherence to treatment of the adolescents

\begin{tabular}{|c|c|c|c|c|}
\hline \multirow[t]{2}{*}{ Variable } & \multirow[t]{2}{*}{$P R$} & \multicolumn{2}{|c|}{$\mathrm{Cl}(95 \%)$} & \multirow[t]{2}{*}{$p$} \\
\hline & & Inferior & Superior & \\
\hline Age (years) & 0.92 & 0.82 & 1.04 & 0.189 \\
\hline \multicolumn{5}{|l|}{ Housing } \\
\hline Owner & 1.00 & & & \\
\hline Not owner & 0.80 & 0.60 & 1.05 & 0.109 \\
\hline \multicolumn{5}{|l|}{ Tried alcohol } \\
\hline No & 1.00 & & & \\
\hline Yes & 0.86 & 0.69 & 1.07 & 0.167 \\
\hline \multicolumn{5}{|c|}{ Friends do drugs } \\
\hline No & 1.00 & & & \\
\hline Yes & 0.77 & 0.60 & 0.98 & 0.035 \\
\hline
\end{tabular}

Source: Elaborated by the author based on data from the city of Piracicaba $P R$ Prevalence Ratio, Cl Confidence Interval

Table 3 shows that only the fact of having friends who did drugs influenced the prevalence of adherence to dental treatment $(p=0.035)$; and the prevalence of adherence decreased by $23 \%$ in patients with friends who did drugs.

\section{Discussion}

The present study revealed that low adherence to dental treatment among adolescents was associated in isolation with socioeconomic factors (type of housing) and behavioral factors such as alcohol consumption and friendships. However, in the joint analysis of the variables, proximity of friends who used illicit drugs was revealed to be the significant factor for lower adherence to treatment.

The variable 'type of housing', when tested alone was statistically significant with the outcome, the use of dental services was associated with socioeconomic factors, among others. In a nationwide study, the researchers found that the number of people who did not have access to dental health services was 16 times higher among those in need, and that this population also had the greatest difficulty in receiving care when they sought the service. In addition to the lack of care to meet the demand, another factor was the perception that people had about the quality of care provided by public health services, leading to the population seeking private services [27].

According to the WHO [28], there are six dimensions involved in adherence to treatment: individual characteristics of the patient (gender, age, ethnicity, marital status, educational level and socioeconomic level), presence of the disease (chronicity, symptoms and consequences), cultural habits (perception of disease, beliefs, knowledge on the problem), aspects related to the treatment (cost, effects, therapeutic protocols), institution (public health policy, organization of services) and relationship with the health team [29].

Therefore, subjects do not adhere to treatment by their will alone, as is the common opinion, but adherence is structured in a multidimensional manner [30]. In childhood, for example, family behavior influences children's access to dental appointments [31]. Thus, the use of services is low in schoolchildren whose mothers have low schooling and worse economic conditions [32, 33].

However, a qualitative study with adolescents found that among the reasons for non-adherence to dental treatment were the absence of priority and neglect of care. This was because the need to attend the consultation probably had no meaning in the context of adolescents, because it was of less importance in their daily lives [20]. According to Leão et al. (2015) [34], adolescents accessed the service mainly for curative treatment, and sought care due to toothache or esthetics issues [35]. These findings supported the fact that socioeconomic factors were less important for the outcome in the study. In this study, the issue of adherence was individual and not programmatic, since adolescents did not have problems with access to health services.

Consumption of alcohol and illicit drug use among adolescents is a worldwide concern [36]. Despite the Child and Adolescent Statute (ECA) [37] having classified the sale, supply and delivery of substances capable of causing dependence in children or adolescents as criminal actions, it has been observed that these (criminal) actions were frequently practiced in daily life. Both the permissiveness of families and society as well as the lack of supervision contribute to drug experimentation among children and adolescents [36].

Consequently, a research in a Brazilian state revealed the high prevalence of alcohol consumption (24\%) and other drugs (2.3\%) in 8th graders [38]. The percentages were higher in the present study, considering the studied age range and the methodological approach.

Most adolescents first experienced alcohol at home $65(20 \%)$, a finding similar to that in the literature [39, 40]. Thus, health education strategies for this population should consider a family approach, since the family can be a facilitator of access to and consumption of alcohol. To achieve this, inter-departmental actions, involving health and community need to be elaborated, or even including this approach in education, as suggested in the proposal developed by the Health in School Program (PSE) [41].

The motivation for alcohol use among adolescents was in the narcotic effect and socialization with their peers, whereas the search for illicit drugs referred to the escape 
from personal and family problems [42]. The illicit drugs had a lower prevalence of consumption (4\%) when compared with alcohol $(46 \%)$, corroborating results of other Brazilian studies [42, 43].

Important to emphasize is the fact that the use of drugs by friends was associated with non-adherence to dental treatment. This reflected the effect of the influence of the friends on the adoption of health care [41, 42]. Important to point out is that the use of illicit and licit substances may not be a socially acceptable behavior, and may lead to respondents omitting the fact of their use in questionnaires, even when these are self-applied. There was a loss of 149 individuals, equivalent to $31.5 \%$ of the total sample, was due to: change of address or contact telephone number - 131 (88\%); Transfer to another municipality - 9 (1\%) and refusal of new participation - 9 (1\%).

In Brazil, the National Health System (SUS) is a public entity and offers the population services of low, medium and high complexity. Low complexity, or Primary Care, coordinates the action of health prevention and promotion, elaborated and provided in a multi-professional manner by the Family Health Teams. Within the FHS, there are the Oral Health Teams (ESB), responsible for dental assistance and preventive care for a certain number of families [44]. Therefore, the adolescents who participated in the present research, received dental attendance by SUS, thus, the results obtained may contribute to the strategies of promotion, prevention and adherence to dental treatment by those individual who use the public system. The ESB needs to increasingly observe the relations existent between patients and the environment in which they live, including their family and friendship relationships, particularly where the care of adolescents is concerned.

The main limitation the study, of course, is related to the non-response rate, since we had difficulty locating important part of the sample of adolescents, although they have been sought in schools where they studied, in the PHCU, and also in their homes (there were often three attempts find them). However, as relevance of this study is due to the professional has the opportunity to understand the expectations and characteristics of individuals who do not follow the recommended treatment, which allows more individualized interventions to improve adherence and hence provide a more qualified service.

\section{Conclusion}

Adolescents who consumed alcohol and socialized with friends who did illicit drugs had greater difficulty in adhering to dental treatment. Therefore, adherence to dental treatment was largely associated with individual behaviors and friendship relationships, rather than with socioeconomic factors.

\section{Abbreviations}

ECA: Child and Adolescent Statute; ICF: The Informed Consent Form; SUS: Unified Health System; WHO: World Health Organization

\section{Acknowledgments}

The authors thank the volunteers.

Funding

The authors acknowledge with thanks, the financial support received from FAPESP - Foundation for Research of the State of São Paulo (scholarship \# 2013/17340-9). The funding bodies had no role in the design, collection, analysis, interpretation of data or in writing the manuscript.

\section{Availability of data and materials}

The datasets used and analyzed during the present study will be available from the corresponding author on reasonable request.

\section{Authors' contributions}

SLF and JVB participated in the conception, design, and data collection. IPC participated in writing the article. YWC and AC Pereira participated in the critical review. All authors read and approved the final manuscript.

\section{Ethics approval and consent to participate}

The study was approved by the Research Ethics Committee of the Piracicaba Dental School, University of Campinas (UNICAMP) (protocol number \#027/ 2011) in accordance with the Ethics approval and consent to participates laid down in the 1964 Declaration of Helsinki and its later amendments. Terms of Free and Informed Consent were obtained from the parents before starting the study.

\section{Consent for publication}

Not applicable.

\section{Competing interests}

The authors declare that they have no competing interests.

\section{Publisher's Note}

Springer Nature remains neutral with regard to jurisdictional claims in published maps and institutional affiliations.

\section{Author details}

${ }^{1}$ Department of Community Dentistry, Piracicaba Dental School, State University of Campinas, Av. Limeira, 901, P.O. BOX 52, Piracicaba, SP 13414-903, Brazil. '2Department of Community Dentistry, Piracicaba Dental School, State University of Campinas, Av. Limeira, 901, P.O. BOX 52, Piracicaba, SP 13414-903, Brazil. ${ }^{3}$ Department of Clinical and Social Dentistry, Federal University of Paraíba, João Pessoa, Brazil.

Received: 11 September 2017 Accepted: 22 November 2018 Published online: 19 December 2018

\section{References}

1. Unodc.United Nations Office for Drug Control and Crime Prevention.World Drug Report 2007 [accessed on Oct 2016]. Available from: http://www. unodc.org/documents/about-unodc/AR06_fullreport.pdf.

2. Unifesp. II Levantamento Nacional de Álcool e Drogas (LENAD) - 2012. São Paulo: Instituto Nacional de Ciência e Tecnologia para Políticas Públicas de Álcool e Outras Drogas (INPAD), 2014. [accessed on Mar 2018]. Available from: https://inpad.org.br/wp-content/uploads/2014/03/ Lenad-II-Relat\%C3\%B3rio.pdf

3. OMS. Organização Mundial da Saúde. Neurociências: consumo e dependência de substâncias psicoativas. World Health Organization; 2004. [accessed sep 2016]. Available from: http://www.who.int/substance_abuse/ publications/en/Neuroscience_P.pdf

4. Alavarse GMA, Carvalho MDB. Álcool e adolescência: o perfil de consumidores de um município do norte do Paraná. Esc Anna Nery Ver Enferm Dec. 2006;10(3):408-16.

5. Unicef. Fundo das Nações Unidas para a Infância. O direito de ser adolescente: oportunidade para reduzir vulnerabilidades e superar desigualdades. Brasília: DF:Unicef; 2011. 
6. Saito MI. Adolescência, cultura, vulnerabilidade e risco. Pediatria (São Paulo). 2000;22:217-9.

7. Peres MA, Sheiham A, Liu P, Demarco FF, Silva AE, Assunção MC, et al. Sugar consumption and changes in dental caries from childhoodto adolescence. J Dent Res. 2016;95(4):388-94.

8. Aguirre-Zero O, Westerhold C, Goldsworthy R, Maupome G. Identification of barriers and beliefs influencing engagement by adult and teen Mexican-Americans in oral health behaviors. Community Dent Health. 2016:33(1):44-7.

9. Sanchez RM, Ciconelli RM. Conceitos de acesso à saúde. Ver Panam Salud Publica [Internet]. 2012 [cited Nov 09 2016]; 31(3): 260-268.

10. Paiva DD, Bersusa AAS, Escuder MML. Avaliação da assistência ao paciente com diabetes e/ou hipertensão pelo Programa Saúde da Família do Município de Francisco Morato, São Paulo, Brasil. Cad Saude Publica. 2006; 22(2):377-85.

11. Bertolozzi MR, Nichiata LYI, Takahashi RF, Ciosak SI, Hino P, Val LF, et al. Os conceitos de vulnerabilidade e adesão na Saúde Coletiva. Rev Esc Enferm. 2009;43(2):1326-30.

12. Guiney H, Woods N, Whelton H, Morgan K. Predictors of utilization of dental care services in a nationally representative sample of adults. CommunityDent Health. 2011;28(4):269-73.

13. Zlotnick C, Baron-Epel O, Zusman SP, Keinan-Boker L. Trends and predictors of primary dental care health services for adults in Israel. Community Dent Health. 2014;31(4):212-8.

14. Silva LF, Thomaz EB, Freitas HV, Pereira AL, Ribeiro CC, Alves CM. Impact of malocclusion on the quality of life of Brazilian adolescents: a populationbased study. PLoSOne. 2016;30(9):e0162715.

15. Dimberg L, Arnrup K, Bondemark L. The impact of malocclusion on the quality of life among children and adolescents: a systematic review of quantitative studies. Eur J Orthod. 2015:37(3):238-47.

16. Schunk DH, Carbonari JP. Self-efficacy models. In: White $\mathrm{KL}$, editor. Behavioral health: a handbook of health enhancement and disease prevention. London: Pitman Books Ltd; 1984

17. Rego SR, Rego DM. Association between the usage of alcohol by HIV patients and the adherence to the antiretroviral drug treatment: a literature review. J Bras Psiquiatr. 2010;59:70-3.

18. D'amico EJ. Factors that impact adolescents' intentions to utilize alcoholrelated prevention services. J Behav Health Serv Res. 2005;32(3):332-40.

19. Vazquez FL, Cortellazzi KL, Gonçalo CS, Bulgareli JV, Guerra LM, Tagliaferro ESP, et al. Estudo qualitativo sobre as justificativas de adolescentes para a não adesão ao tratamento odontológico. Ciência \& Saúde Coletiva. 2015; 20(7):2147-56. https://doi.org/10.1590/1413-81232015207.04502014.

20. Vazquez FL, Cortellazzi KL, Kaieda AK, Bulgarelli JV, Mialhe FL, Ambrosano GMB, et al. Individual and contextual factors related to dental caries in underprivileged Brazilian adolescents. BMC Oral Health. 2015;20:15-6.

21. Bulgareli JV. Adesão ao tratamento odontológico de adolescentes em situação de vulnerabilidade social: Abordagem quanti qualitative [Tese de Doutorado] Faculdade de Odontologia de Piracicaba- UNICAMP; 2016.

22. World Health Organization. Child and adolescent health and development (WHO). Adolescents: the sheer numbers. [internet]. 2015 [accessed on $15 \mathrm{Jul}$ 2018]. Available from: http://www.who.int/child-adolescenthealth/overview/ Ahd/ahdsheer.htm

23. Meneghim MC, Kozlowski FC, Pereira AC, Ambrosano GMB. Meneghim ZMAP. A socioeconomic classification and the discussion related to prevalence of dental caries and dental fluorosis. Ciência \& Saúde Coletiva. 2007;12(2):523-9.

24. Goes PSA. The prevalence and impact of dental pain in Brazilian schoolchildren and their families. [doctoral dissertation]. London: Department of Epidemiology and Public Health, University College London; 2001.

25. Kirkwood BR, Sterne JA. Essential medical statistics, vol. 2. Massachusetts: Blackwell Science; 2006.

26. McCullagh P, Nelder JA. Generalized linear models. 2. New York: Chapman and Hall; 1989.

27. Barros AJD, Bertoldi AD. Desigualdades na utilização e no acesso a serviços odontológicos: uma avaliação em nível nacional. Ciênc Saúde Coletiva 2002; 4:709-117.

28. Haynes RB. Determinants of compliance: the disease and the mechanics of treatment. Baltimore MD: Johns Hopkins University Press; 1979.

29. Cramer J. Identifying and improving compliance patterns. In: Cramer JA, Spilker B, editors. Patient compliance in medical practice and clinical trials. New York: Raven Press; 1991. p. 387-92.
30. Leite SN, Vasconcellos MPC. Adesão à terapêutica medicamentosa: elementos para a discussão de conceitos e pressupostos adotados na literatura. Ciência \& Saúde Coletiva. 2003;8(3):775-82.

31. Badri P, Saltaji H, Flores-Mir C, Amin M. Factors affecting children's adherence to regular dental attendance: a systematic review. J Am Dent Assoc. 2014;145(8):817-28. https://doi.org/10.14219/jada.2014.49.

32. Ardenghi TM, Vargas-Ferreira F, Piovesan C, Mendes FM. Age of first dental visit and predictors for Oral health care utilisation in pre school children. Oral health Prev Dent. 2012;10(1):17-27.

33. Goettems ML, Ardenghi TM, Demarco FF, Romano AR, Torriani DD. Children's use of dental services: influence of maternal dental anxiety, attendance pattern, and perception of children's quality of life. Community Dent Oral Epidemiol. 2012;40(5):451-8.

34. Leão MM, Garbin CAS, Moimaz SAS, Rovida TAS. Oral health and quality of life: an epidemiological survey of adolescents from settlement in Pontal do Paranapanema/SP, Brazil. Cien Saude Colet. 2015;20(11):3365-7.

35. Klages U, Erbe C, Sandru SD, Brüllman D, Wehrbein H. Psychosocial impact of dental aesthetics in adolescence: validity and reliability of a questionnaire across age-groups. Qual Life Res. 2015;24(2):379-90.

36. OMS.Organização Mundial da Saúde. Health for the World's adolescents: a second chance in the second decade: World Health Organization; 2014

37. Brasil. Casa Civil. Lei n. 8.069, de 13 de julho de 1990. Dispõe sobre o Estatuto da Criança e do Adolescente e dá outras providências. Diário Oficial da República Federativa do Brasil [Internet], Brasília (DF), 1990 jul 16 [accessed July 10 2016]. Seção 1:13563. Available from: http://www.planalto. gov.br/ccivil_03/leis/18069.htm.

38. Tavares BF, Béria JU, Lima MS. Fatores associados ao uso de drogas entre adolescentes escolares. RevSaude Publica 2004 dez;38(6):787-796.

39. Elicker E, Palazzo LS, Aerts DRGC, Alves GG, Câmara S. Uso de álcool, tabaco e outras drogas por adolescentes escolares de Porto Velho-RO. Brasil Epidemiologia e Serviços de Saúde. 2015;24(3):399-410.

40. Vieira PC, Aerts DRGC, Freddo SL, Bittencourt A, Monteiro L. Uso de álcool, tabaco e outras drogas por adolescentes escolares em município do Sul do Brasil. Cadernos de Saúde Pública. 2008;24(11):2487-98.

41. Brasil. Ministério da Saúde. Secretaria de Atenção à Saúde. Saúde na escola [Internet]. Brasília: Ministério da Saúde; 2009 [accessed 9 Oct 2016]. 96 p. (Série B. Textos Básicos de Saúde, Cadernos de Atenção Básica, n. 24). Available from: http://189.28.128.100/dab/docs/publicacoes/cadernos_ab/ abcad24.pdf.

42. Chimeli IV, Nogueira MJ, Pimenta DN, Schall VT. A abstração do risco e a concretude dos sujeitos: uma reflexão sobre os comportamentos de risco no contexto da adolescência. Physis: Revista de Saúde Coletiva. 2016;26(2): 399-415.

43. Jinez MLJ, Souza JRM, Pillon SC. Uso de drogas e fatores de risco entre estudantes de ensino médio. Rev Lat Am Enfermagem. 2009;17(2):246-52.

44. Brasil. Ministério da Saúde. Secretaria de Atenção à Saúde. Departamento de Atenção Básica. Coordenação Nacional de saúde Bucal. [Internet] Brasília. 2004. [accessed on Fev 2018]. Available from: http://bvsms.saude.gov.br/ bvs/publicacoes/politica_nacional_brasil_sorridente.pdf.

Ready to submit your research? Choose BMC and benefit from:

- fast, convenient online submission

- thorough peer review by experienced researchers in your field

- rapid publication on acceptance

- support for research data, including large and complex data types

- gold Open Access which fosters wider collaboration and increased citations

- maximum visibility for your research: over $100 \mathrm{M}$ website views per year

At $\mathrm{BMC}$, research is always in progress.

Learn more biomedcentral.com/submission 